\title{
Micropollutants Identification Affecting the Nearby Environment from Highway Runoff: The Case Study of Cyprus Highway
}

\author{
Antonis A. Zorpas, ${ }^{1}$ Lampis A. Ilia, ${ }^{1}$ Irene Voukkali, ${ }^{2}$ and Vassilis Inglezakis ${ }^{3}$ \\ ${ }^{1}$ Faculty of Pure and Applied Science, Environmental Conservation and Management, Cyprus Open University, P.O. Box 12794, \\ Latsia, 2252 Nicosia, Cyprus \\ ${ }^{2}$ Department of Research and Development, Institute of Environmental Technology and Sustainable Development (I.E.T.S), \\ P.O. Box 34073, 5309 Paralimni, Cyprus \\ ${ }^{3}$ School of Engineering, Chemical Engineering Department, Nazarbayev University, Astana, Kazakhstan
}

Correspondence should be addressed to Antonis A. Zorpas; antoniszorpas@yahoo.com

Received 20 December 2014; Revised 2 February 2015; Accepted 2 February 2015

Academic Editor: Meng Nan Chong

Copyright (C) 2015 Antonis A. Zorpas et al. This is an open access article distributed under the Creative Commons Attribution License, which permits unrestricted use, distribution, and reproduction in any medium, provided the original work is properly cited.

\begin{abstract}
Road/highway surfaces accumulate significant quantities of pollutants including nutrients, heavy metals, and polycyclic hydrocarbon aromatic (PHAs). Traffic characteristics (vehicle speed, traffic load, etc.), climate, long dry wet periods, and rainfall event intensity and duration are regarded as important factors in generating pollutants in high way runoff (HRO). Regarding rainfall control, most of the road is served by drainage ditches which collect the runoff and direct it to the nearest natural water courses. This paper focuses on the estimation of pollutant that is coming from two several highways (to the airport and to the biggest industrial area) in Cyprus. Overall, more than 100 different samples were collected and analysed over a period of two years. Several parameters were determined like PHA, COD, electronic conductivity (EC), total suspended solid (TSS), total dissolved solid (TDS), pH, fats and oils (FOG), T. Coliforms, $\mathrm{NO}_{3}, \mathrm{NO}_{2}, \mathrm{NH}_{4}, \mathrm{SO}_{4}, \mathrm{Cl}$, As, $\mathrm{Ba}, \mathrm{Bi}, \mathrm{Cd}, \mathrm{Co}, \mathrm{Cr}, \mathrm{Cu}, \mathrm{Fe}, \mathrm{Hg}, \mathrm{Mn}, \mathrm{Mo}, \mathrm{Ni}, \mathrm{P}, \mathrm{Pb}$, and $\mathrm{Zn}$. The results indicated that the first flush consists of major pollution due to the fact that all parameters are in high levels. As the rainfall continues the pollution decreases but the influence to the nearby areas of the runoff is high.
\end{abstract}

\section{Introduction}

During wet weather period, the surface deposited micropollutants are washed off and drained into the pipe network, which finally enter the aquatic environment. Under heavy traffic conditions, the depositions of toxic pollutants are usually more important than those of other nonpoint pollutants such as nitrogen and phosphorus. During runoff, the deposited pollutants are washed off mostly at the early stage of runoff [1]. Road construction and traffic affect the nearby environment. Physical and chemical characteristics of nearby land, air, cultivations, and water bodies [2] are mainly affected by roads effluent (cars emission, runoffs). Water pollution by road-borne chemicals has received little attention compared with other deleterious effects. Numerous factors (type of vehicles, weather conditions, and type of road) may affect the quality of a road runoff, but since vehicles are the main source of pollution, traffic volume is usually proportional to the quantity of pollutants in runoff [3-5]. In Israel it was mentioned by some researchers $[6,7]$ that during autumn rain high concentrations of pollutants especially in first flush were found. When rain falls, the runoff washes pollutants off streets, parking lots, construction sites, industrial storage yards, and lawns. Urban runoff carries a mixture of pollutants from cars and trucks, outdoor storage piles, muddy construction sites, and pesticide spills. Efficient systems of ditches, gutters, and storm sewers carry the polluted runoff to nearby lakes and streams, bypassing wastewater treatment systems. Motor vehicle emissions, drips of crankcase oil, vehicle tyre wear, and asphalt road surfaces are all diffuse sources of chemical contaminants in urban environments. During rainfall, these contaminants are washed from roofs, roads, 
and other surfaces into the stormwater system and then discharged into surface waterways and estuarine environments. Heavy metals copper $(\mathrm{Cu})$, lead $(\mathrm{Pb})$, and zinc $(\mathrm{Zn})$ and polycyclic hydrocarbon aromatics (PHAs) are of particular concern in such runoff due to their prevalence, toxicity to aquatic organisms, and persistence in the environment $[8,9]$. Urban storm runoff was identified as one of the leading causes of degradation in the quality of receiving waters. Storm runoff from urban area contains various pollutants and carries a large pollutant load, so it exerts a great influence on receiving waters [8].

Runoff from both urban and rural areas is loaded with nutrients such as phosphorus and nitrogen [10]. Phosphorus is the nutrient of greatest concern because it promotes weed and algae growth in lakes and streams. Like sediment, phosphorus concentrations are lower in urban runoff than in rural runoff, but annual phosphorus loads per acre are at least comparable to rural areas. Because phosphorus compounds attach to soil particles, areas with high sediment loads also produce high phosphorus loads. This means that construction sites are significant sources of phosphorus as well as sediment. Runoff may also contain a variety of chemicals, metals, and faecal material of human and animal origin. There are several impediments to reuse of runoff for nonpotable and potable purposes in urban residential areas. The most significant issue appears to be associated with the presence of pathogens $[11,12]$.

The levels of bacteria found in urban runoff almost always exceed public health standards [13]. Research shows these high levels of bacteria are typical of runoff from small as well as large cities in Wisconsin. Sources of bacteria in urban runoff include sanitary sewer overflows, pets, and populations of urban wildlife. One of the special challenges of urban watersheds is toxic pollution. Toxic pollutants are substances that may cause death, disease, or birth defects or that may interfere with reproduction, child development, or disease resistance. Metals are the best understood toxic pollutants in urban runoff. It is recently indicated that cities confirm that runoff from small as well as large cities is contaminated with metals such as lead and zinc [14]. Lead has historically been used as an "indicator" for other toxic pollutants in urban stormwater because it is relatively easy to monitor and its dangers are well documented. Lead is a problem for both humans and aquatic life. Its human health effects include damage to the nervous system and kidneys, high blood pressure, and digestive disorders. Lead can also be toxic to aquatic life. Zinc is another metal in urban runoff which commonly violates water quality standards. While zinc does not create human health problems, it can be toxic to aquatic life. In fact, zinc is even more likely than lead to exceed levels that kill aquatic life. The primary source of many metals in urban runoff is vehicle traffic. Concentrations of zinc, cadmium, chromium, and lead appear to be directly correlated with the volume of traffic on streets that drain into a storm sewer system. Streets and parking lots are the primary sources of lead in several urban areas.

Runoff from urban and suburban areas generates numerous pollutants. The areas include residential areas, parks, commercial areas, industrial areas, and road/highways [15].
It has been neglected for several decades, due to the fact that road runoff transports low concentrations of pollutants in huge volumes of water. The USA much earlier than Europe assessed that from 4 to $11 \%$ of impacts in the water quality were caused by stormwater [16]. The US EPA [16] stated that diffuse sources were responsible for $70 \%$ of the presence of COD, oil, and zinc, $90 \%$ of the presence of total Kjeldahl nitrogen and faecal coliform, and $95 \%$ of the load in iron. It is interesting to notice that two studies on road runoff in Portugal $[17,18]$ showed values of TSS and COD that surpass the permitted level for discharge of point effluents (Annex XVIII of the Portuguese law, Dec.-Lei number 236/98) in $15 \%$ and $50 \%$ of the samples, respectively, for COD, and in $62 \%$ of the samples for TSS. TSS are important pollutants in stormwater runoff degrading the quality of the receiving water by making it turbid, inhibiting plant growth, and reducing species diversity $[1,19]$.

This paper focuses on the estimation of pollutant that is coming from two several highways (to the airport and to the biggest industrial area).

\section{Materials and Methods}

Cyprus has developed one of the most modern road networks in Europe. According to 2002 statistics, the road network in the Republic of Cyprus-administered areas of Cyprus consists of about $7206 \mathrm{~km}$ of paved and $4387 \mathrm{~km}$ of unpaved roads [20]. Although the first motorway in Cyprus, A1, was completed as recently as October 1985, the country already has the most motorway $\mathrm{km}$ per capita $(38.6 \mathrm{~km} / 100000$ inhabitants) amongst all European Union members [20]. The Public Works Department of the Ministry of Communications and Works is responsible for the maintenance, improvement, and construction of motorways, the majority of rural and interurban road network, and the main urban roads. The Municipalities are responsible for the secondary and local urban roads; the District Administration Authorities are responsible for the paved and unpaved district (tertiary) roads and village roads. The Forestry Department is responsible for most unpaved roads in forest areas; this is in order to accommodate the administration and protection of forests [20].

The samplings were carried out in two points, $\mathrm{A}$ and B (Figure 1). Area A is at the end of highway A3 (main road Paralimni-Larnaca-airport) close to the entrance of the airport. Area A is used by private cars, taxi, motorcycles, lorries, and heavy loads and belongs in SCI/SPA Natura. Area $\mathrm{B}$ belongs to industrial area. In an industrial area, there are more heavy vehicles instead of cars and family vehicles. Also Area B is very close to Natura side (Rizoelias). Area B was chosen as the road joining the motorway A3 Aradippou village to the point outside the industrial area of Larnaca. The first sample known as first flush was collected immediately with the first rain and then every 15, 30, and $60 \mathrm{~min}$ and $24 \mathrm{~h}$ of rainfall.

The runoff was collected in polypropylene containers $(18 \mathrm{~L})$ placed at the bottom of storm-drains on both sides of the road. We collected a total of $100 \mathrm{~L}$ of first runoff (first flush) and $20 \mathrm{~L}$ (approximately) of the rest. We first collect 


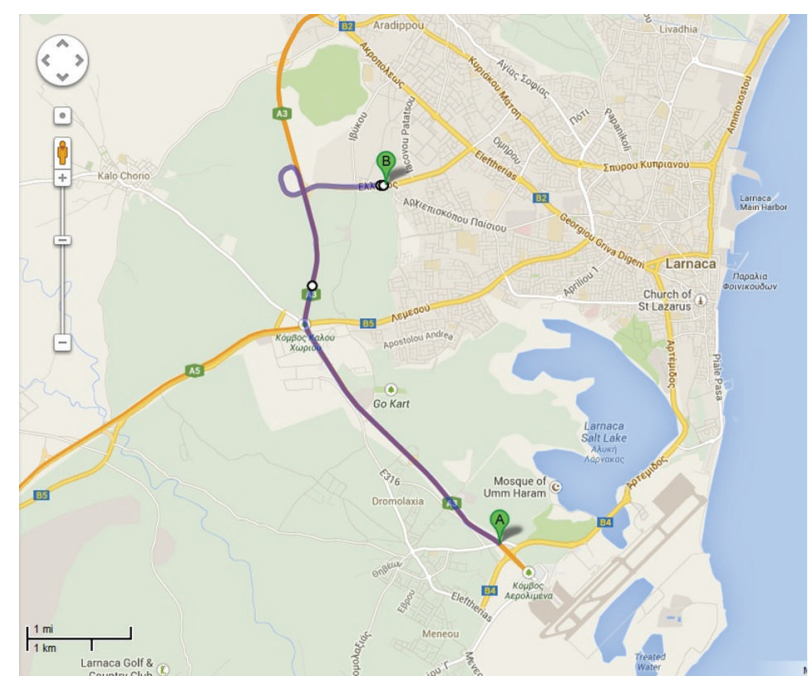

(a)

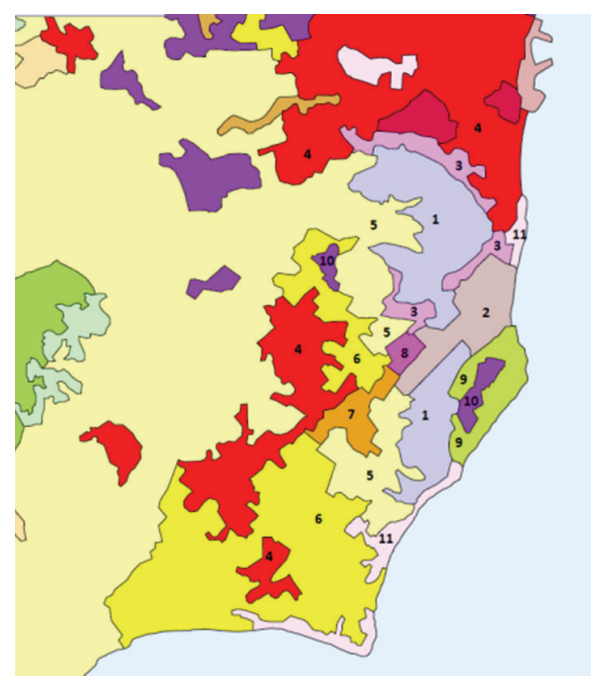

(b)

FIGURE 1: Sampling points in highway (points A and B) and land use around the collected point (1: saltmarsh, 2: airport, 3: small forest in urban area, 4: technical urban area, 5: agricultural areas without irrigation systems, 6: agricultural areas with intensive cultivation and irrigation system, 7: growing fruit cultivations with irrigation, 8: international airport, 9: areas with natural undergrowth, 10: industrial/livestock areas, and 11: athletic areas, beaches) (Google Maps).

first runoff and at the moment that we collect a total of $100 \mathrm{~L}$ we stopped. Then the rest of the samples were collected automatically with respect to the time set. The containers had a float element made of PVC pipe and a polystyrene ball that sealed them once they were filled and prevented the inflow of additional water, thus ensuring the collection of the very first road runoff (first flush) only. The samples were kept in a refrigerator at $4^{\circ} \mathrm{C}$ until they were analysed.

Overall, more than 100 different samples were collected and analysed over a period of two years. Several parameters were determined like PHA, COD, EC, TSS, TDS, pH, FOG, T. Coliforms, $\mathrm{NO}_{3}, \mathrm{NO}_{2}, \mathrm{NH}_{4}, \mathrm{SO}_{4}, \mathrm{Cl}, \mathrm{As}, \mathrm{Ba}, \mathrm{Bi}, \mathrm{Cd}, \mathrm{Co}$, $\mathrm{Cr}, \mathrm{Cu}, \mathrm{Fe}, \mathrm{Hg}, \mathrm{Mn}, \mathrm{Mo}, \mathrm{Ni}, \mathrm{P}, \mathrm{Pb}$, and $\mathrm{Zn}$ using standard methods of analysis as referred to from several authors [2123]. Soluble metal concentrations in water fraction of runoff were examined after filtering with a $0.45 \mathrm{~mm}$ mesh filter. For the statistical analysis SPSS v. 2.0 was used.

\section{Result and Discussion}

Table 1 presents the results of the first flush in two different years in Area A. In the same table the legislation limits for agricultural and drinkable purpose are presented according to National Law [24] and international standard. Table 2 presents the difference between points A and B. Figures 25 present the micropollutant variations in runoff samples without the first flush sample in Area A (but with the 50 samples per sampling time).

Comparing the runoff of Areas A and B most of the parameters in Area B and especially heavy metals concentration after the period from $15 \mathrm{~min}$ to $24 \mathrm{~h}$ are considered to be higher. This happens for the following main reasons as (a) Area B is an industrial area and more heavy loaders are using the specific roads and (b) in the industrial area there are several industries and as a result of their activities they release particles into the atmosphere containing contaminants (such as heavy metals), which are then dropped on the road surface.

According to Table 1, runoff pollution is considered to be high. This usually happens in the first flush according to some researchers $[8,25]$. Although there are no specific limits for COD, first flush COD is considered to be high (2750-3050 ppm). Total Coliforms are also too high due to the dead animals or animal's letterings and due to the soil. According to St Laurent and Mazumder, [26] the microbial load presented in runoff affect surface and underground waters. Nitrogen forms like $\mathrm{NO}_{3}, \mathrm{NO}_{2}$, and $\mathrm{NH}_{4}$ can create the eutrophication phenomenon in surface waters [27, 28]. The first flush samples present high concentration of nitrogen forms. The present nitrogen forms are due to the strong agricultural activities in the area [29] and due to the traffic activities [30]. The $\mathrm{pH}$ value is up to 8.57. This is due to the road surface, dust, and soil that exist in the surface. Similar phenomenon was observed in Iraq [31] as the alkalinity that exists in the dust may transfer through the runoff of the rainwater and from there to the other water bodies. FOGs concentration is more than $5 \mathrm{ppm}$ which in the maximum concentration for agricultural proposed. Most of the heavy metals are considered to be high in the first flush but at the end the metals consternation is under the maximum limits that ICP plasma could recognize. However the determination of $\mathrm{Bi}$ is an interesting part as $\mathrm{Bi}$ exists on the streets due to the presence of galvanic coatings on vehicles [32]. Therefore, there are no any specific limits for $\mathrm{Bi}$, however specific attention must be taken into consideration due to its unclear and controversial chemical action [33].

$\mathrm{Ba}$ and $\mathrm{Sr}$ are in high concentrations. Sr is a metal that already exists in the vehicles tires up to $70 \mathrm{mg} / \mathrm{g}$ [34]. The study area is located at the end of the A3 motorway where 


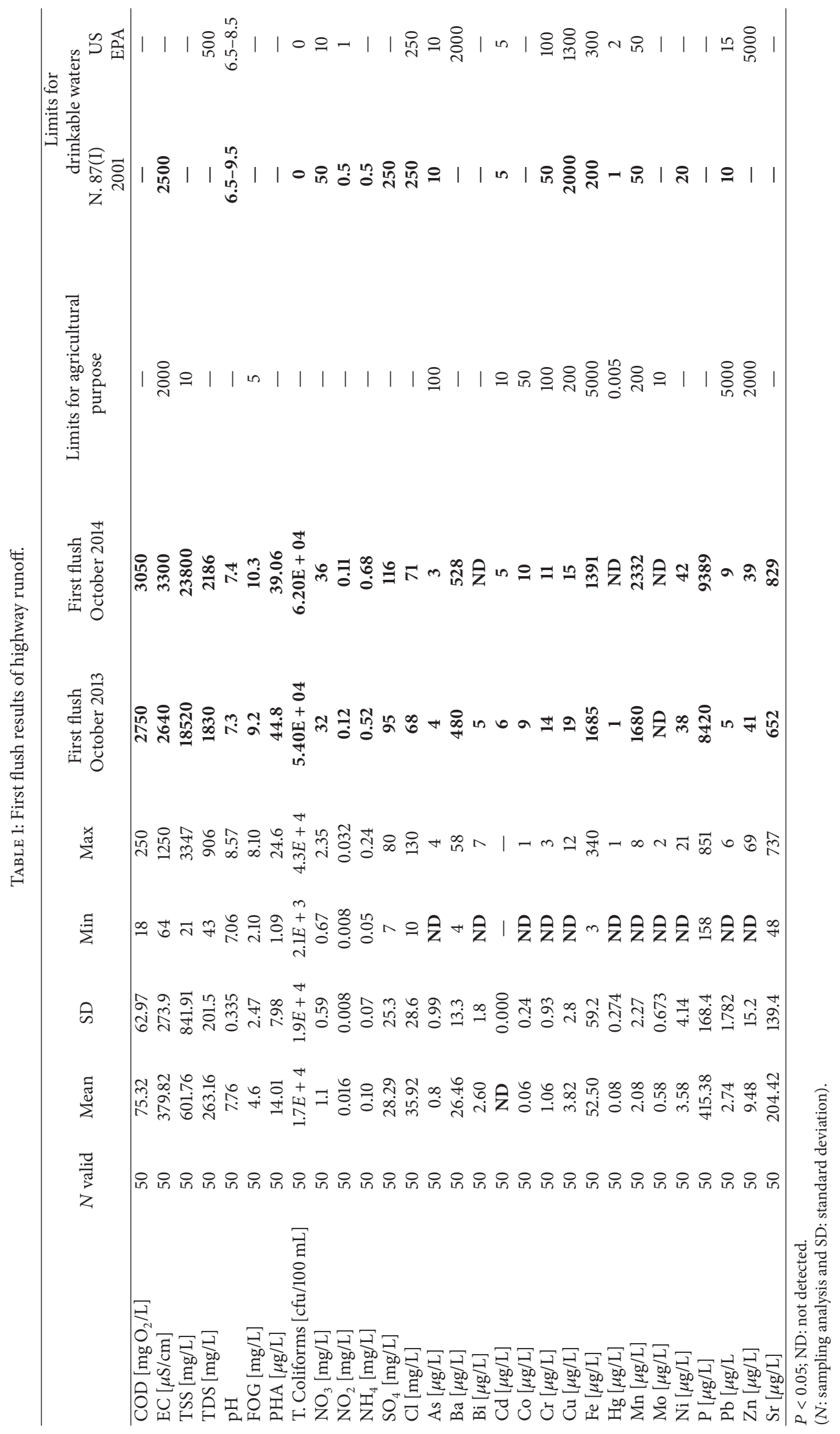


TABLE 2: Runoff physicochemical characteristics with respect to sampling time.

\begin{tabular}{|c|c|c|c|c|c|c|c|c|c|c|}
\hline & \multicolumn{5}{|c|}{$\begin{array}{c}\text { Area A } \\
\text { Time }\end{array}$} & \multicolumn{5}{|c|}{$\begin{array}{c}\text { Area B } \\
\text { Time }\end{array}$} \\
\hline & $15 \mathrm{~min}$ & $30 \mathrm{~min}$ & $45 \mathrm{~min}$ & $60 \mathrm{~min}$ & $24 \mathrm{~h}$ & $15 \mathrm{~min}$ & $30 \mathrm{~min}$ & $45 \mathrm{~min}$ & $60 \mathrm{~min}$ & $24 \mathrm{~h}$ \\
\hline & Mean & Mean & Mean & Mean & Mean & Mean & Mean & Mean & Mean & Mean \\
\hline $\mathrm{COD}\left[\mathrm{mg} \mathrm{O}_{2} / \mathrm{L}\right]$ & 98 & 62 & 40 & 42 & 42 & 173 & 148 & 137 & 122 & 115 \\
\hline $\mathrm{EC}[\mu \mathrm{S} / \mathrm{cm}]$ & 415 & 336 & 219 & 200 & 259 & 905 & 738 & 746 & 638 & 495 \\
\hline TSS [mg/L] & 1075 & 591 & 123 & 57 & 228 & 2738 & 1325 & 1265 & 721 & 201 \\
\hline TDS [mg/L] & 283 & 220 & 156 & 135 & 172 & 593 & 606 & 586 & 435 & 333 \\
\hline $\mathrm{pH}$ & 7.66 & 7.76 & 7.83 & 7.94 & 7.75 & 7.65 & 7.57 & 7.60 & 7.63 & 8.02 \\
\hline FOG $[\mathrm{mg} / \mathrm{L}]$ & 6.60 & 4.10 & 2.60 & 2.20 & 2.10 & . & . & . & . & 8.10 \\
\hline PHA $[\mu \mathrm{g} / \mathrm{L}]$ & 5.14 & 3.99 & 5.18 & 3.33 & 2.66 & 2.98 & 3.94 & 2.05 & 2.01 & 1.97 \\
\hline T. Coliforms [cfu/100 mL] & $4.2 E+4$ & $3.1 E+3$ & $2.3 E+3$ & $2.1 E+3$ & $2.5 E+3$ & . & . & . & . & $2.3 E+4$ \\
\hline $\mathrm{NO}_{3}[\mathrm{mg} / \mathrm{L}]$ & 1.09 & 0.84 & 0.81 & 0.67 & 0.69 & . & . & . & . & 2.35 \\
\hline $\mathrm{NO}_{2}[\mathrm{mg} / \mathrm{L}]$ & 0.020 & 0.013 & 0.012 & 0.009 & 0.008 & . & . & . & . & 0.032 \\
\hline $\mathrm{NH}_{4}[\mathrm{mg} / \mathrm{L}]$ & 0.10 & 0.05 & 0.05 & 0.10 & 0.07 & . & . & . & . & 0.24 \\
\hline $\mathrm{SO}_{4}[\mathrm{mg} / \mathrm{L}]$ & 32 & 10 & 14 & 24 & 7 & . & . & . & . & 80 \\
\hline $\mathrm{Cl}[\mathrm{mg} / \mathrm{L}]$ & 34 & 27 & 20 & 20 & 25 & 89 & 86 & 70 & 61 & 61 \\
\hline As $[\mu \mathrm{g} / \mathrm{L}]$ & 1 & 0 & 0 & 1 & 1 & 2 & 1 & 1 & 1 & 1 \\
\hline $\mathrm{Ba}[\mu \mathrm{g} / \mathrm{L}]$ & 36 & 26 & 22 & 17 & 23 & 45 & 33 & 28 & 24 & 25 \\
\hline $\mathrm{Bi}[\mu \mathrm{g} / \mathrm{L}]$ & 3 & 2 & 2 & 2 & 3 & 4 & 4 & 4 & 3 & 3 \\
\hline $\mathrm{Cd}[\mu \mathrm{g} / \mathrm{L}]$ & 0 & 0 & 0 & 0 & 0 & 0 & 0 & 0 & 0 & 0 \\
\hline $\operatorname{Co}[\mu \mathrm{g} / \mathrm{L}]$ & 0 & 0 & 0 & 0 & 0 & 1 & 0 & 0 & 0 & 0 \\
\hline $\operatorname{Cr}[\mu \mathrm{g} / \mathrm{L}]$ & 1 & 1 & 1 & 1 & 1 & 3 & 3 & 2 & 1 & 1 \\
\hline $\mathrm{Cu}[\mu \mathrm{g} / \mathrm{L}]$ & 5 & 3 & 2 & 3 & 3 & 10 & 5 & 3 & 3 & 6 \\
\hline $\mathrm{Fe}[\mu \mathrm{g} / \mathrm{L}]$ & 84 & 58 & 51 & 28 & 79 & 23 & 13 & 7 & 8 & 8 \\
\hline $\mathrm{Hg}[\mu \mathrm{g} / \mathrm{L}]$ & 0 & 0 & 0 & 0 & 0 & 0 & 0 & 0 & 0 & 0 \\
\hline $\mathrm{Mn}[\mu \mathrm{g} / \mathrm{L}]$ & 2 & 2 & 2 & 1 & 3 & 3 & 4 & 0 & 4 & 2 \\
\hline Mo $[\mu \mathrm{g} / \mathrm{L}]$ & 1 & 1 & 0 & 0 & 0 & 2 & 2 & 1 & 1 & 1 \\
\hline $\mathrm{Ni}[\mu \mathrm{g} / \mathrm{L}]$ & 7 & 5 & 5 & 3 & 2 & 1 & 1 & 1 & 1 & 2 \\
\hline $\operatorname{Sr}[\mu \mathrm{g} / \mathrm{L}]$ & 204 & 186 & 156 & 134 & 117 & 543 & 456 & 406 & 275 & 232 \\
\hline $\mathrm{P}[\mu \mathrm{g} / \mathrm{L}]$ & 545 & 414 & 408 & 357 & 418 & 557 & 340 & 327 & 211 & 303 \\
\hline $\mathrm{Pb}[\mu \mathrm{g} / \mathrm{L}]$ & 3 & 3 & 2 & 3 & 3 & 2 & 4 & 3 & 4 & 4 \\
\hline $\mathrm{Zn}[\mu \mathrm{g} / \mathrm{L}]$ & 17 & 15 & 9 & 11 & 5 & 3 & 1 & 1 & 0 & 9 \\
\hline
\end{tabular}

$P<0.05$.

drivers of vehicles have to brake. This logically leads to enhanced catalysis of tires, more in this region than in other regions which are not required to brake very often. Those metals are naturally presented in soils and in roads surface and that's why are presented in waters.

EC were 32-65 times in the road first runoff higher than the agricultural limits. Also $\mathrm{Hg}$ was 200 times, Mn was 8.4-11.6, and FOG was 1.84-2.05 times higher than the proposed limits. Although most parameters do not have any proposed limits those are considered to be high. Despite the apparent threat to aquatic biota, and therefore the relatively high environmental pollution potential from road runoff in Cyprus, no control measures are currently in use. Elron et al. [35] suggested that decreased habitat availability in heavily developed urban areas has led to exploitation of water bodies of limited suitability for the toad reproduction. However, no acute effect of pollutants on habitats' water quality has been identified [36]. We proposed that road runoff pollution can be a major cause for a qualitative decrease of temporary pools used by amphibians, especially in heavily developed urban areas. We suggested that an immediate implementation of control actions for road runoff in roads located near water bodies and agricultural fields, is needed. This is especially important for arid and semiarid countries like Cyprus, where water resources are scarce and agricultural fields are close to highways. Usually the fields close to Areas A and B are used to cultivate barley (Hordeum vulgare), wheat (Triticum), corn (Zea mays), ladino (Trifolium), potatoes (Solanum tuberosum), spinach (Spinacia oleracea), celery (Apium graveolens), and artichoke (Cynara cardunculus var. scolymus). The European Commission on December 19 (2006) sets out specific maximum levels for certain contaminants on foodstuffs [37]. This regulation sets limits in order to protect public health and to keep contaminants at levels which toxicologically are acceptable. In order to protect public health, maximum levels for several contaminants and per species have been set. For example, $\mathrm{NO}_{3}$ maximum concentration was set on $3000 \mathrm{mg} / \mathrm{kg}$ for fresh spinach (Spinacia oleracea) and 


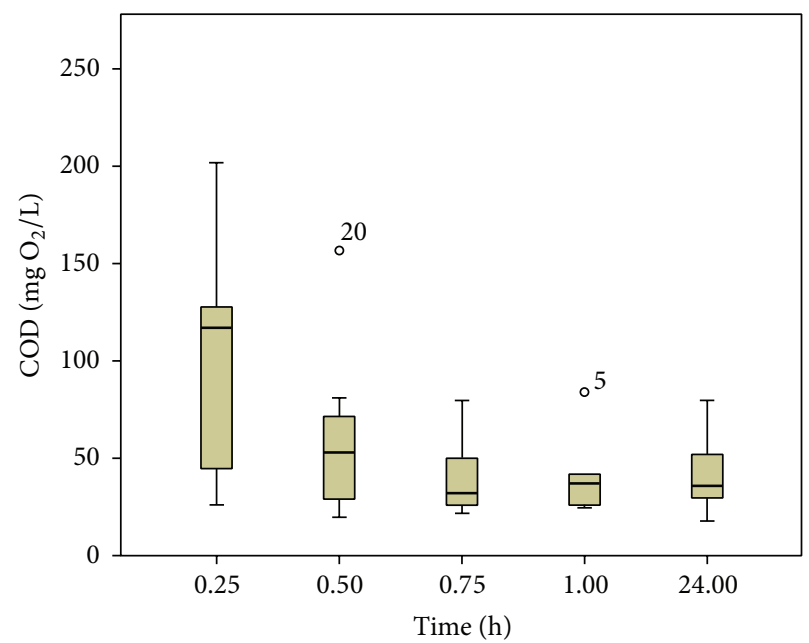

(a)

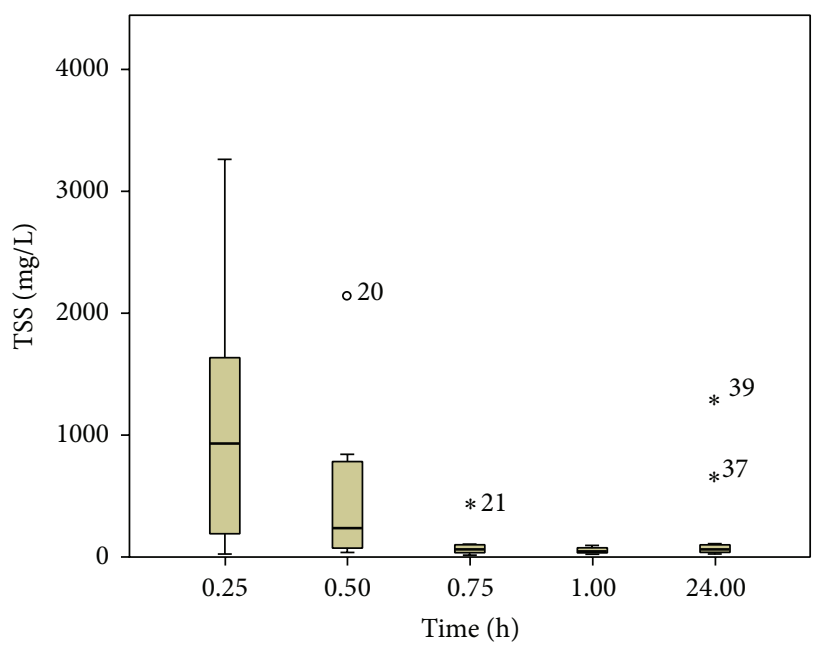

(c)

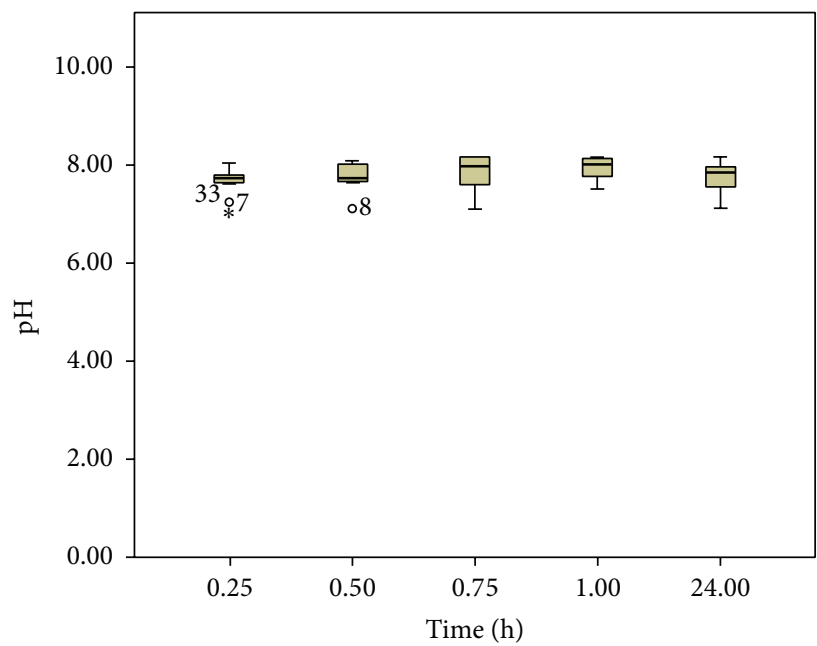

(e)

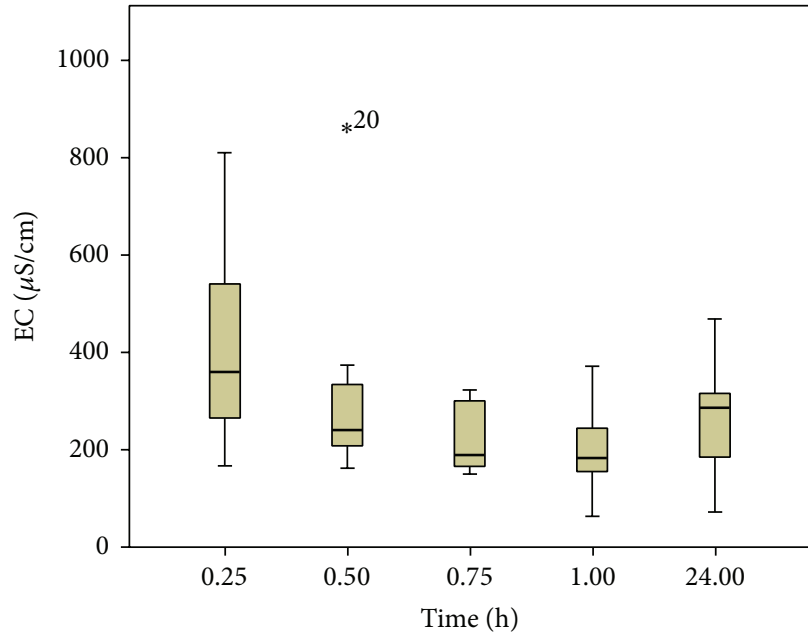

(b)

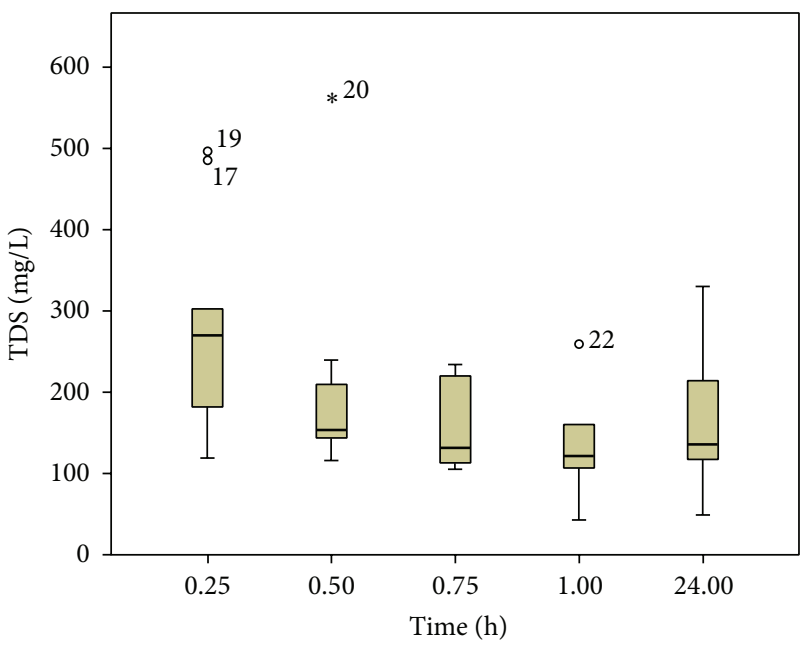

(d)

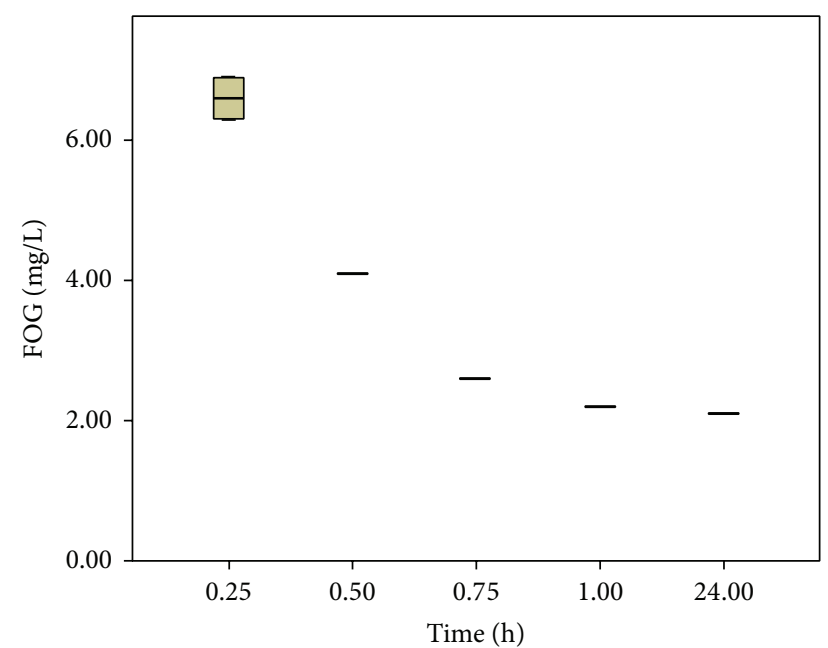

(f)

FIGURE 2: Micropollutant (COD, EC, TSS, TDS, pH, and FOG) variations in runoff samples without the first flush sample in Area A (but with the 50 samples per sampling time). 


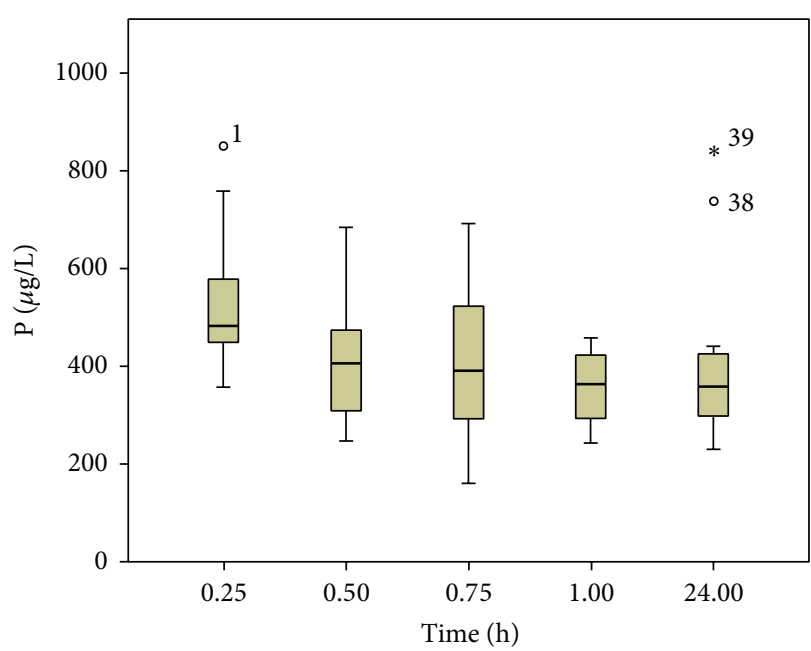

(a)

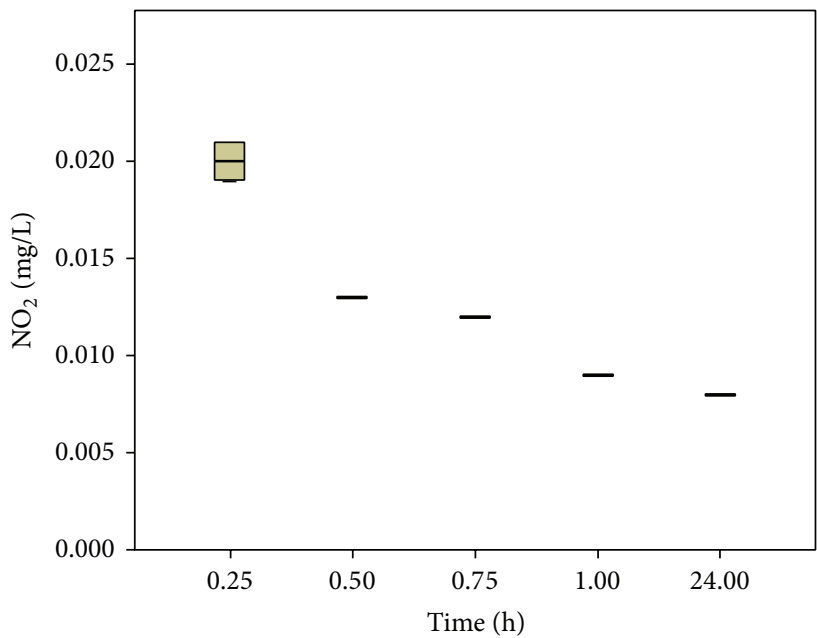

(c)

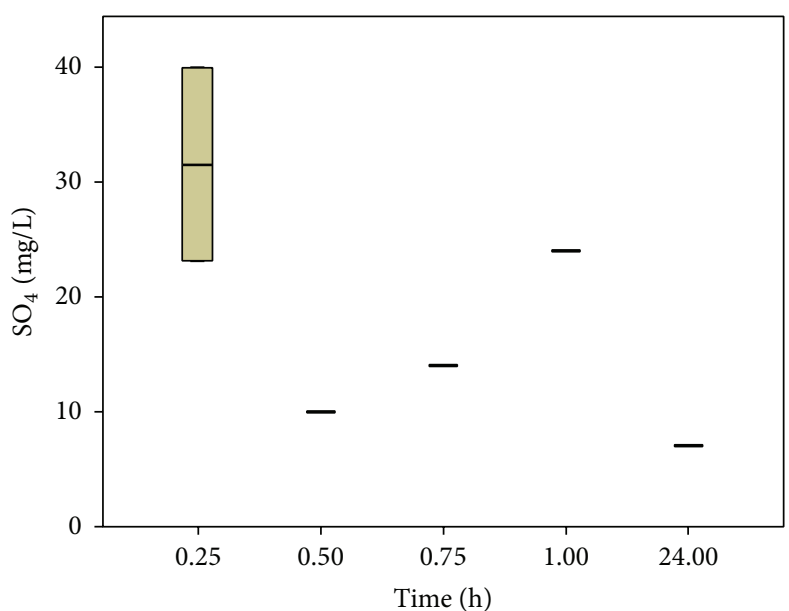

(e)

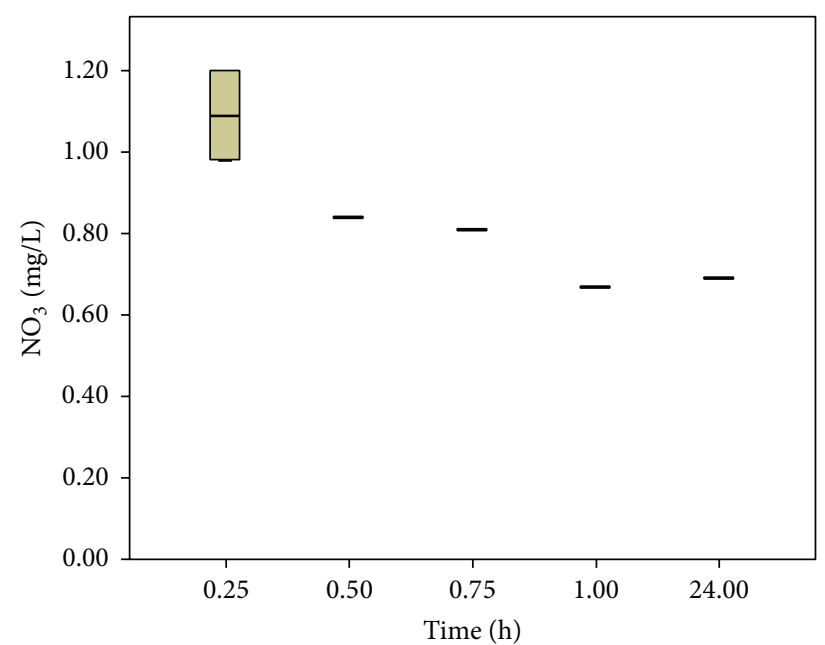

(b)

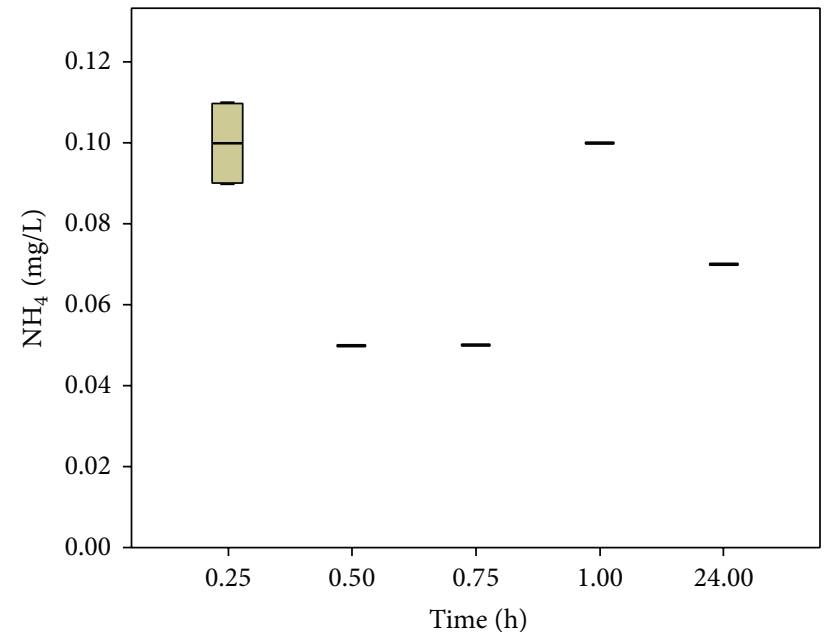

(d)

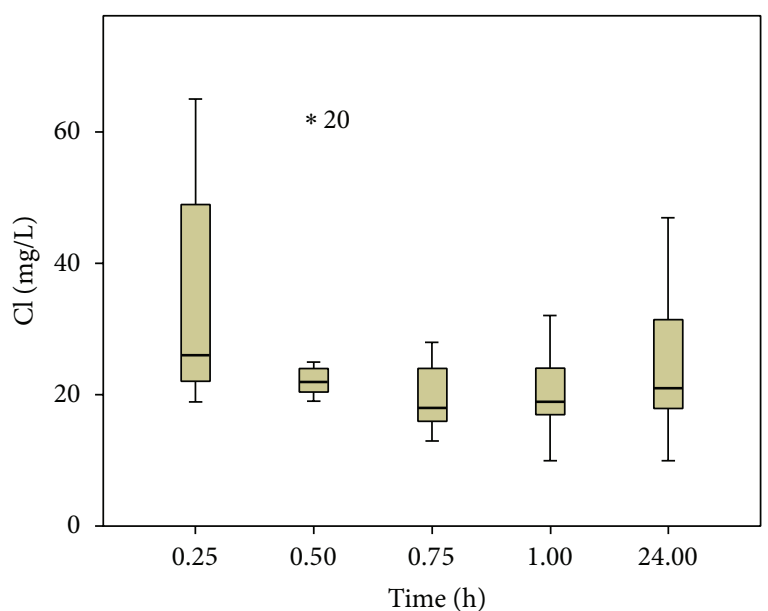

(f)

Figure 3: Micropollutant $\left(\mathrm{P}, \mathrm{NO}_{3}, \mathrm{NO}_{2}, \mathrm{NH}_{4}, \mathrm{SO}_{4}\right.$, and $\mathrm{Cl}$ ) variations in runoff samples without the first flush sample in Area $\mathrm{A}$ (but with the 50 samples per sampling time). 


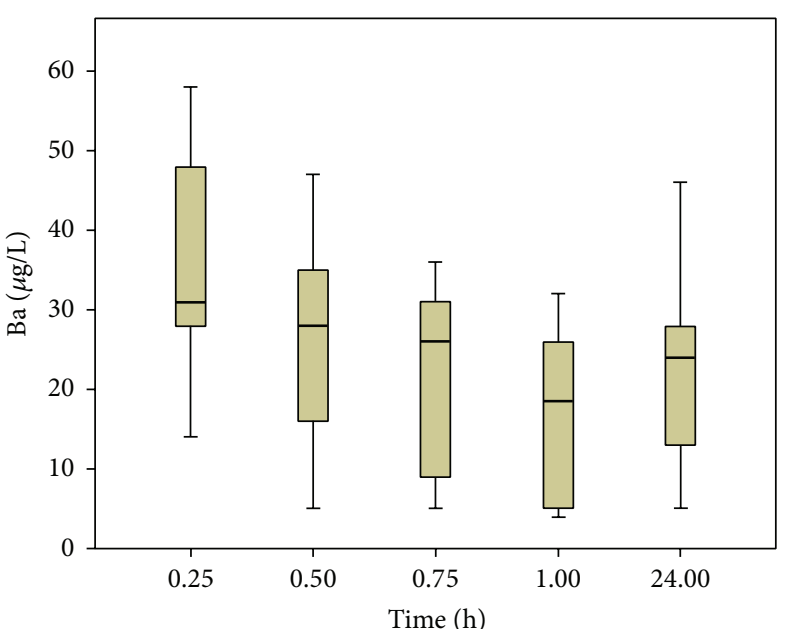

(a)

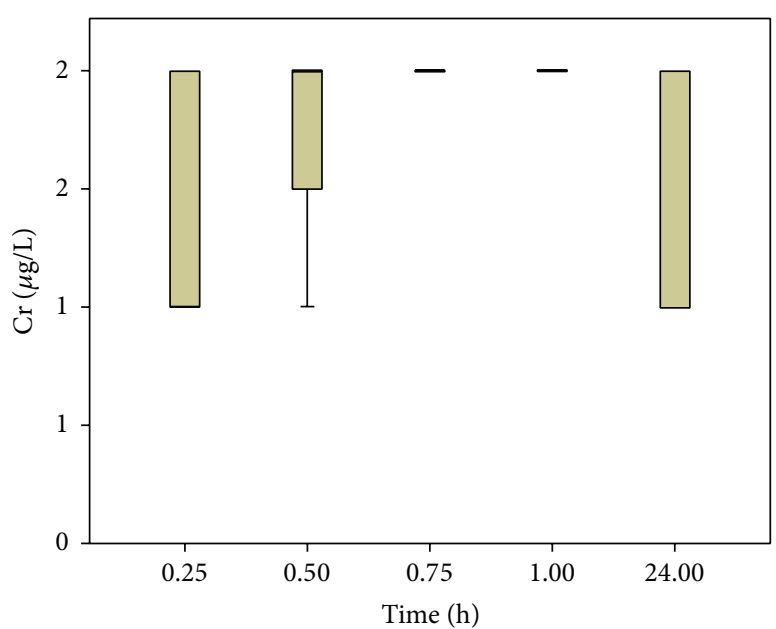

(c)

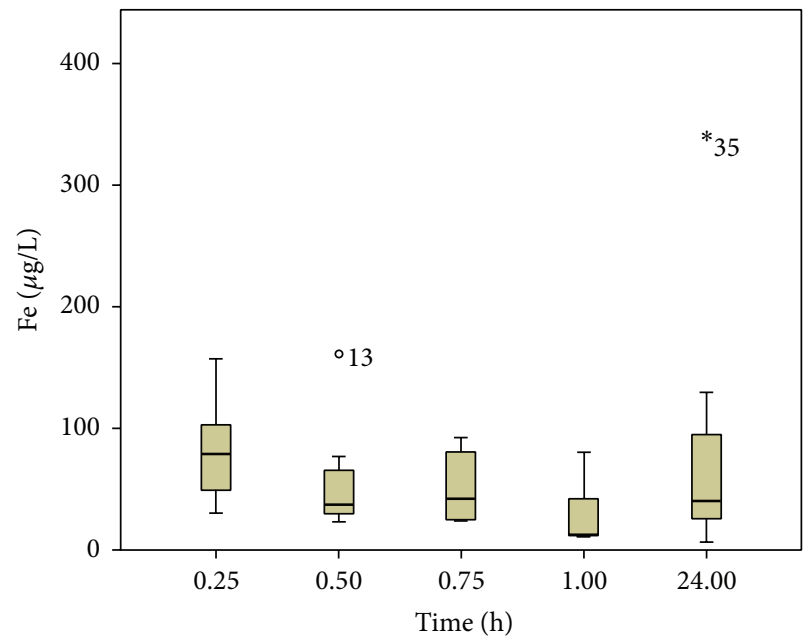

(e)

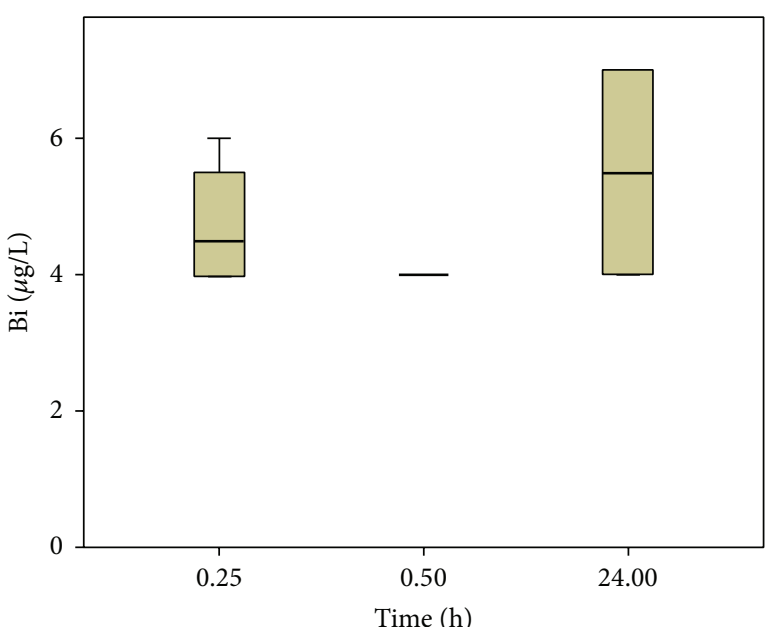

(b)

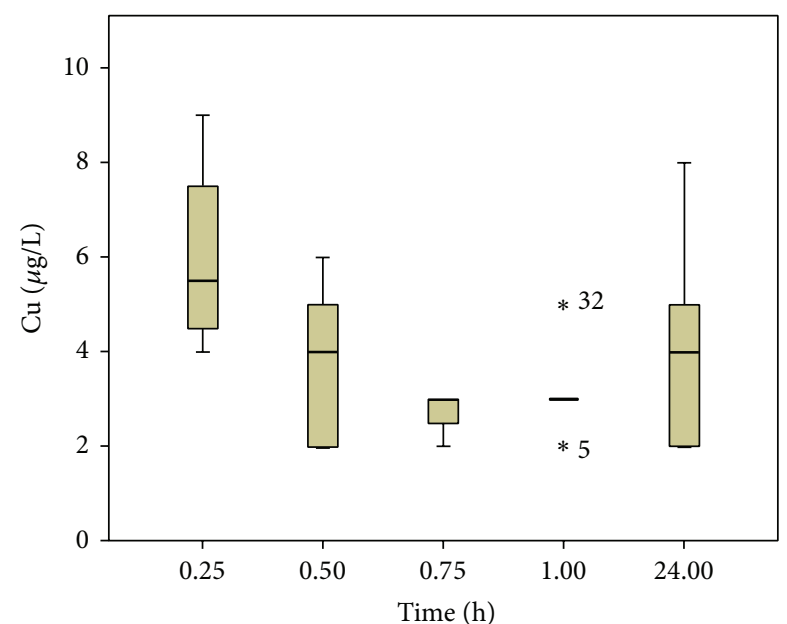

(d)

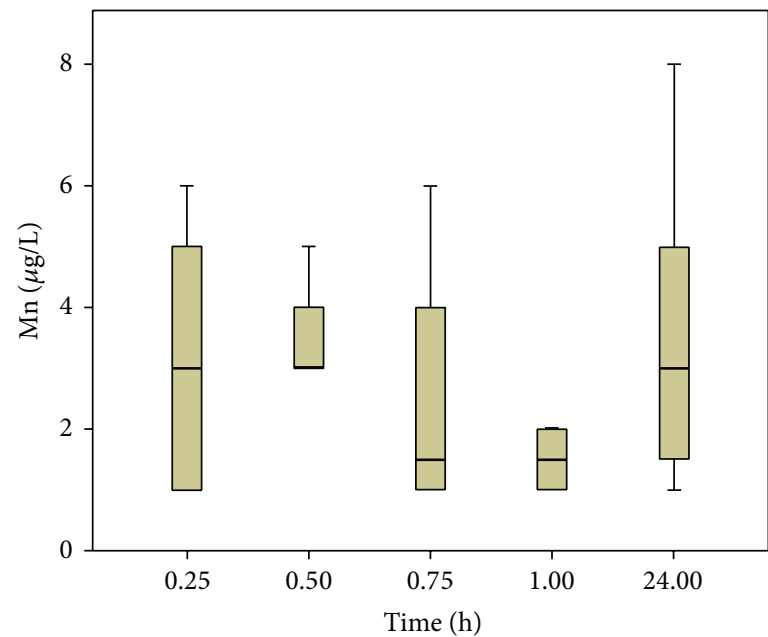

(f)

Figure 4: Metals micropollutant ( $\mathrm{Ba}, \mathrm{Bi}, \mathrm{Cr}, \mathrm{Cu}, \mathrm{Fe}$, and $\mathrm{Mn}$ ) variations in runoff samples without the first flush sample in Area A (but with the 50 samples per sampling time). 


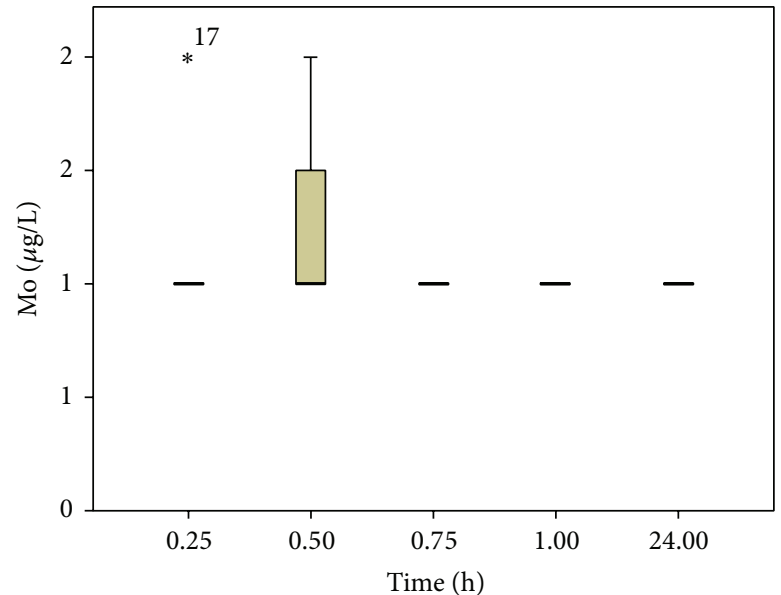

(a)

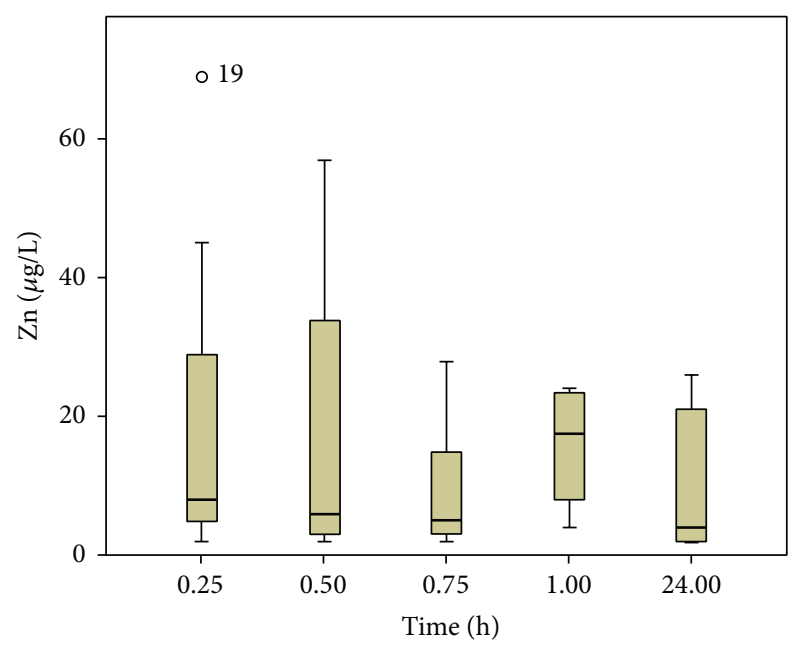

(c)

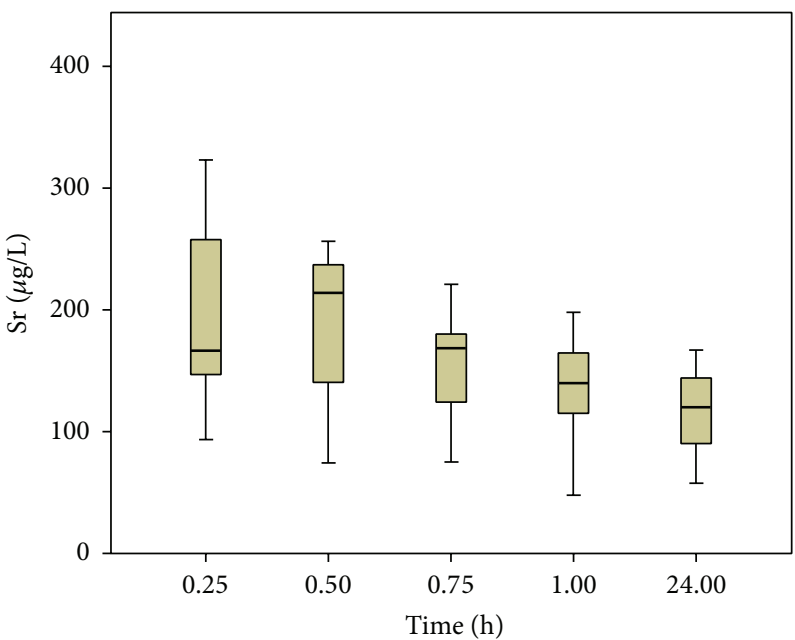

(e)

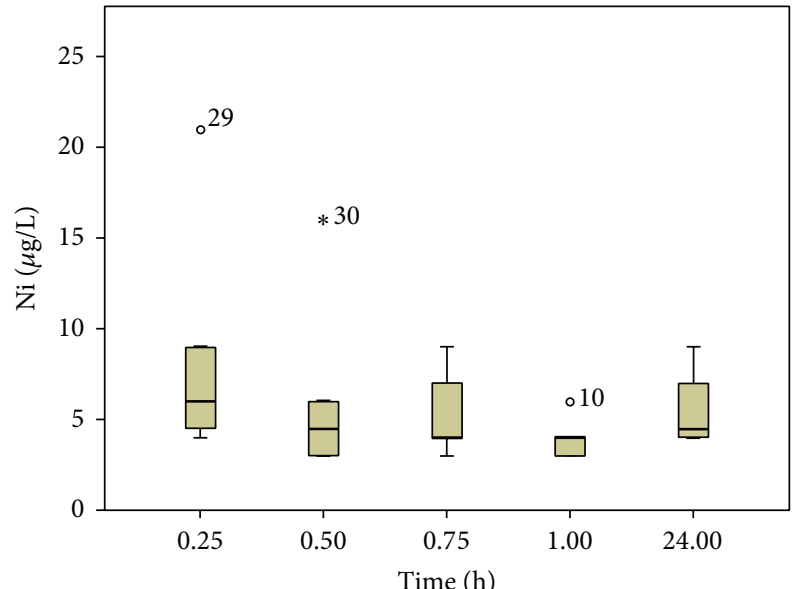

(b)

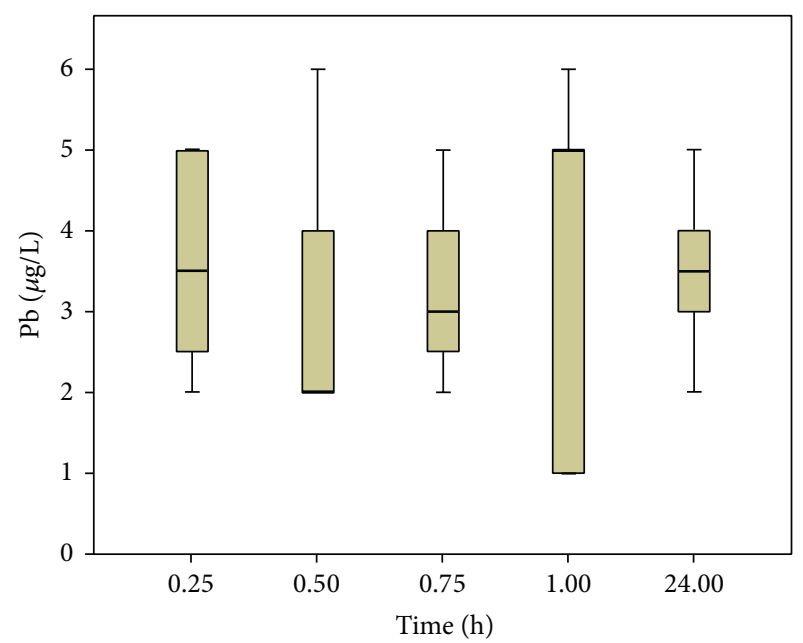

(d)

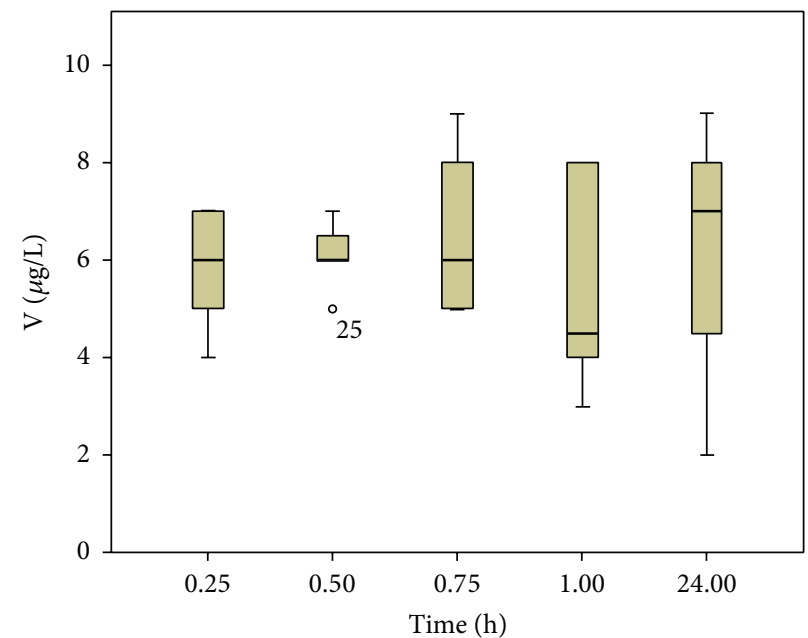

(f)

FIgURE 5: Metals micropollutant ( $\mathrm{Mo}, \mathrm{Ni}, \mathrm{Zn}, \mathrm{Pb}, \mathrm{Sr}$, and $\mathrm{V}$ ) variations in runoff samples without the first flush sample in Area A (but with the 50 samples per sampling time). 
$4000 \mathrm{mg} / \mathrm{kg}$ for lettuce (Lactuca sativa L.) grown in the open air. Cd maximum concentration for wheat (Triticum) was set on $0.20 \mathrm{mg} / \mathrm{kg}$ of wet weight while for potatoes it was at $0.050 \mathrm{mg} / \mathrm{kg}$ of wet weight. Maximum limits for $\mathrm{Pb}$ were set up to $0.10 \mathrm{mg} / \mathrm{kg}$ of wet weight of potatoes. Some of the results obtained in Tables 1 and 2 are above those limits indicating that highway runoff may affect nearby environment. Environmental conditions play significant role in the transformation of those contaminants in the nearby environment. Emission from roads may transfer (after that rain stops) as a result from high winds eroding agricultural lands, tilling soils and harvesting agricultural crops, processing agricultural products, and trafficking from livestock.

There is no specific system or any proposed strategy until now for the treatment of highways runoff in the country. Usually runoffs from highways are forward (in horizontal or vertical level; depending on the road level) in the nearby agricultural fields or on natural ponds or in the close natural river leading to the sea (infrequent). This is very important as both examined areas and especially Area A are close to protected area. It is not examined in this research but somehow Area A is affected from highways runoff (underground water or surface water may lead to the lake). It is considered to be one of the most important wetlands of Cyprus and it has been declared a Ramsar site, Natura 2000, Special Protected Area under the Barcelona Convention, and Important Bird Area [38, 39]. Many researches mention that, for the treatment of urban runoff, free water surface and constructed wetlands are mostly used according to many researches [40, 41]. However, there are some examples of the use of horizontal flow constructed wetlands from highway runoff in UK $[42,43]$ and Italy [44].

Under heavy traffic conditions, the depositions of toxic compounds such as PHA are usually more important than those of other nonpoint pollutants such as nitrogen and phosphorus. PHA has been recognized as a group of potentially toxic, genotoxic, and carcinogenic chemicals [45]. The US EPA has identified 16 PHA compounds as priority pollutants. Urban runoff is a known important PHA pathway to water environments and aquatic ecosystems $[46,47]$. It has been estimated that $36 \%$ of environmental PHA input is due to urban runoff, with the figure reaching $71 \%$ for higher molecular weight compounds. Mean concentration of total PHAs in first flush runoff (PHAs, 16 compounds) for Area A was $44.8 \mu \mathrm{g} / \mathrm{L}$, while the mean value of the total analysis sample was $14.01 \mu \mathrm{g} / \mathrm{L}$. In Heraklion highway runoff (Crete) according to Terzakis et al. [48], the total PHAs of 16 samples present average value of $12.01 \mu \mathrm{g} / \mathrm{L}$.

\section{Conclusions}

Road/highway runoff is considered a major source of pollution in developed urban areas. The phenomenon of first flush was caused by the first part of runoff, flushing off the accumulated pollutants from the urban surface and sewers before the large part of runoff arrived at the outfall. The first flush is influenced by many factors, such as a watershed area, rainfall intensity, impervious area, and antecedent dry weather period. The highway runoff is mainly affected by traffic characteristics (mean vehicle speed, traffic load, etc.), climate, long dry wet periods, and rainfall event intensity and duration which are regarded as important factors in generating pollutants in HRO. Additionally, experiments indicated that many pollutants somehow abutted to the nearby environment as well as highways runoffs must separately collected and treated.

\section{Conflict of Interests}

The authors declare that there is no conflict of interests regarding the publication of this paper.

\section{References}

[1] R. K. Aryal, H. Furumai, F. Nakajima, and M. Boller, "Dynamic behavior of fractional suspended solids and particle-bound polycyclic aromatic hydrocarbons in highway runoff," Water Research, vol. 39, no. 20, pp. 5126-5134, 2005.

[2] L. H. Gunderson, A. P. Clevenger, A. T. Cooper et al., Assessing and Managing the Ecological Impacts of Paved Roads, The National Academy Press, Washington, DC, USA, 2005.

[3] M. E. Barrett, R. D. Zuber, and E. R. Collins, "A review and evaluation of literature pertaining to the quantity and control of pollution from highway runoff and construction," Report 95-5, 1-180, Bureau of Engineering Research, the University of Texas at Austin, J.J. Pickle Research Campus, Austin, Tex, USA, 1995.

[4] M. E. Barrett, L. B. Irish Jr., F. M. Malina Jr., and R. I. Charbeneau, "Characterization of highway runoff in Austin, Texas area," Journal of Environmental Engineering, vol. 124, pp. 131-137, 1998.

[5] D. Drapper, R. Tomlinson, and P. Williams, "Pollutant concentrations in road runoff: Southeast Queensland case study," Journal of Environmental Engineering, vol. 126, no. 4, pp. 313$320,2000$.

[6] M. Kayhanian and S. Borroum, "Regional highway stormwater runoff characteristics in California," in Proceedings of the 72nd Annual Conference on California Water Environment Association, pp. 1-11, California State University, Sacramento (CSUS), University of California, Davis (UCD), California Department of Transportation (Caltrans), Sacramento, Calif, USA, 2000.

[7] H. Lee, S.-L. Lau, M. Kayhanian, and M. K. Stenstrom, "Seasonal first flush phenomenon of urban stormwater discharges," Water Research, vol. 38, no. 19, pp. 4153-4163, 2004.

[8] L. Q. Li, C. Q. Yin, Q. C. He, and L. L. Kong, "First flush of storm runoff pollution from an urban catchment in China," Journal of Environmental Sciences, vol. 19, no. 3, pp. 295-299, 2007.

[9] J. N. Brown and B. M. Peake, "Sources of heavy metals and polycyclic aromatic hydrocarbons in urban stormwater runoff," Science of the Total Environment, vol. 359, no. 1-3, pp. 145-155, 2006.

[10] W. Guo, Y. Fu, B. Ruan, H. Ge, and N. Zhao, "Agricultural nonpoint source pollution in the Yongding River Basin," Ecological Indicators, vol. 36, pp. 254-261, 2014.

[11] E. P. Sauer, J. L. VandeWalle, M. J. Bootsma, and S. L. McLellan, "Detection of the human specific Bacteroides genetic marker provides evidence of widespread sewage contamination of stormwater in the urban environment," Water Research, vol. 45, no. 14, pp. 4081-4091, 2011.

[12] J. P. S. Sidhu, W. Ahmed, W. Gernjak et al., "Sewage pollution in urban stormwater runoff as evident from the widespread 
presence of multiple microbial and chemical source tracking markers," Science of the Total Environment, vol. 463-464, pp. 488-496, 2013.

[13] W. D. Price, M. R. Burchell, W. F. Hunt, and G. M. Chescheir, "Long-term study of dune infiltration systems to treat coastal stormwater runoff for fecal bacteria," Ecological Engineering, vol. 52, pp. 1-11, 2013.

[14] D. Wicke, T. A. Cochrane, and A. O'Sullivan, "Build-up dynamics of heavy metals deposited on impermeable urban surfaces," Journal of Environmental Management, vol. 113, pp. 347-354, 2012.

[15] R. Aryal, S. Vigneswaran, J. Kandasamy, and R. Naidu, "Urban stormwater quality and treatment," Korean Journal of Chemical Engineering, vol. 27, no. 5, pp. 1343-1359, 2010.

[16] M. P. Wanielista and Y. A. Yousef, Stormwater Management, John Wiley \& Sons, 1993.

[17] A. E. Barbosa, M. J. Henriques, and J. N. Fernandes, "Quality of highway runoff in coastal areas: special cases," in Proceedings of the 8th Highway and Urban Environment Symposium, Nicosia, Cyprus, June 2006.

[18] P. A. Antunes and A. E. Barbosa, "Highway runoff characteristics in coastal areas-a case study in Aveiro, Portugal," in Proceedings of the 10th International Conference on Urban Drainage, p. 6, Copenhagen, Denmark, August 2006.

[19] Y. Shammaal and D. Z. Zhu, “Techniques for controlling total suspended solids in stormwater runoff," Canadian Water Resources Journal, vol. 26, no. 3, pp. 359-375, 2013.

[20] Cyprus Statistical Services, 2014, http://www.mof.gov.cy/mof/ cystat/statistics.nsf/index_en/index_en?OpenDocument.

[21] A. A. Zorpas, C. Coumi, M. Drtil, and I. Voukalli, "Municipal sewage sludge characteristics and waste water treatment plant effectiveness under warm climate conditions," Desalination and Water Treatment, vol. 36, no. 1-3, pp. 319-333, 2011.

[22] A. A. Zorpas and V. J. Inglezakis, "Intergraded applied methodology for the treatment of heavy polluted waste waters from olive oil industries," Applied and Environmental Soil Science, vol. 2011, 14 pages, 2011.

[23] APHA, AWWA, and WEF, Standard Methods for the Examination of Water and Wastewater, American Public Health Association, American Water Works Association and Water Environment Federation, Washington, DC, USA, 22nd edition, 2012.

[24] National Cyprus Law N.87(I)/2001, quality of water intended for human consumption.

[25] A. Dorchin and U. Shanas, "Assessment of pollution in road runoff using a Bufo viridis biological assay," Environmental Pollution, vol. 158, no. 12, pp. 3626-3633, 2010.

[26] J.St Laurent and A. Mazumder, "Influence of seasonal and interannual hydro-meteorological variability on surface water fecal coliform concentration under varying land-use composition," Water Research, vol. 48, no. 1, pp. 170-178, 2014.

[27] T. M. Addiscott, Nitrate, Agriculture and the Environment, CABI, Oxfordshire, UK, 2004.

[28] A. A. Ansari, S. S. Gill, and F. A. Khan, "Eutrophiction: threat to aquatic ecosystems," in Eutrophication: Causes, Consequences and Control, A. A. Ansari, S. S. Gill, G. R. Lanza, and W. Rast, Eds., pp. 143-170, Springer, Dordrecht, The Netherlands, 2011.

[29] C. Christophi and C. A. Constantinou, "Nitrogen sources and denitrification potential of Cyprus aquifers, through isotopic investigation on nitrates," in Advances in the Research of Aquatic Environment, vol. 2 of Environmental Earth Sciences, pp. 151-159, Springer, Berlin, Germany, 2011.
[30] M. Kayhanian, B. D. Fruchtman, J. S. Gulliver, C. Montanaro, E. Ranieri, and S. Wuertz, "Review of highway runoff characteristics: comparative analysis and universal implications," Water Research, vol. 46, no. 20, pp. 6609-6624, 2012.

[31] F. Moore and A. Attar, "Rainwater and the resulting runoff chemistry in Shiraz city, Southwest Iran," International Journal of Environmental Studies, vol. 68, no. 5, pp. 703-717, 2011.

[32] N. Pistofidis, G. Vourlias, S. Konidaris, E. Pavlidou, A. Stergiou, and G. Stergioudis, "The effect of bismuth on the structure of zinc hot-dip galvanized coatings," Materials Letters, vol. 61, no. 4-5, pp. 994-997, 2007.

[33] D. González-Weller, C. Rubio, Á. J. Gutiérrez et al., "Dietary intake of barium, bismuth, chromium, lithium, and strontium in a Spanish population (Canary Islands, Spain)," Food and Chemical Toxicology, vol. 62, pp. 856-868, 2013.

[34] E. Apeagyei, M. S. Bank, and J. D. Spengler, "Distribution of heavy metals in road dust along an urban-rural gradient in Massachusetts," Atmospheric Environment, vol. 45, no. 13, pp. 2310-2323, 2011.

[35] E. Elron, A. Gasith, and S. Gaphny, "Increased occupancy of the green toad (Bufo viridis), a possible syndrome of a population in trouble," Israel Journal of Zoology, vol. 51, p. 63, 2005.

[36] E. Elron, Decline of amphibian populations: the case of the Green Toad (Bufo viridis) e processes and biological ecological aspects [Ph.D. thesis], Department of Zoology, Faculty of Life Sciences, Tel-Aviv University, Ramat Aviv, Israel, 2007, (Hebrew).

[37] Commission Regulation (EC) No 1881/2006 of 19 December 2006, setting maximum levels for certain contaminants in foodstuffs, 2006.

[38] S. Iezekiel, C. Makris, and A. Antoniou, "Important Bird Areas of European Union Importance in Cyprus," Birdlife Cyprus, Lefkosia, Cyprus, 2014, http://www.birdlife.org/datazone/country/cyprus/resources.

[39] Department of Environment, 2014, http://www.moa.gov.cy/ moa/environment/environment.nsf/index_gr/index_gr?OpenDocument.

[40] M. Scholz, Wetland Systems to Control Urban Runoff, Elsevier, Amsterdam, The Netherlands, 2006.

[41] J. Vymazal and L. Kröpfelová, Wastewater Treatment in Constructed Wetlands with Horizontal Sub-Surface Flow, Springer, Dordrecht, The Netherlands, 2008.

[42] R. B. E. Shutes, D. M. Revitt, L. N. L. Scholes, M. Forshaw, and B. Winter, "An experimental constructed wetland system for the treatment of highway runoff in the UK," Water Science and Technology, vol. 44, no. 11-12, pp. 571-578, 2001.

[43] D. M. Revitt, P. Worrall, and D. Brewer, "The integration of constructed wetlands into a treatment system for airport runoff," Water Science and Technology, vol. 44, no. 11-12, pp. 469474, 2001.

[44] R. Bresciani, P. Perco, V. La Volpe, and F. Masi, "Constructed wetlands for highway runoff treatment: the Villesse-Gorizia project," in Proceeding of the International Conference on Multi Functions of Wetland Systems, M. Borin and S. Bacelle, Eds., pp. 198-199, Pan SRL, Padova, Italy, 2007.

[45] P. C. Baumann, "Epizootics of cancer in fish associated with genotoxins in sediment and water," Mutation Research: Reviews in Mutation Research, vol. 411, no. 3, pp. 227-233, 1998.

[46] A. Krein and M. Schorer, "Road runoff pollution by polycyclic aromatic hydrocarbons and its contribution to river sediments," Water Research, vol. 34, no. 16, pp. 4110-4115, 2000. 
[47] M. Murakami, F. Nakajima, and H. Furumai, "Modelling of runoff behaviour of particle-bound polycyclic aromatic hydrocarbons (PAHs) from roads and roofs," Water Research, vol. 38, no. 20, pp. 4475-4483, 2004.

[48] S. Terzakis, M. S. Fountoulakis, I. Georgaki et al., "Constructed wetlands treating highway runoff in the central Mediterranean region," Chemosphere, vol. 72, no. 2, pp. 141-149, 2008. 

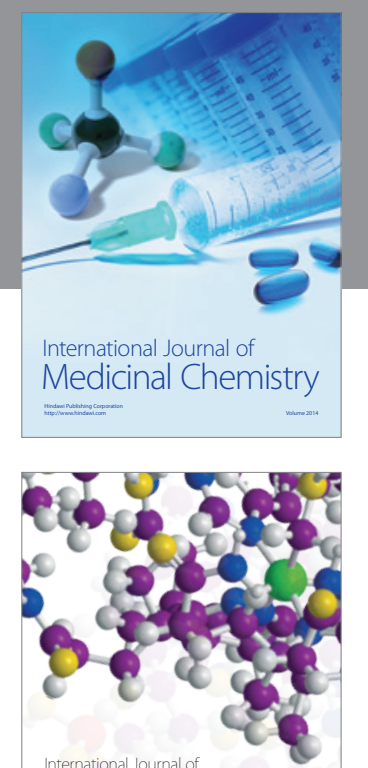

\section{Carbohydrate} Chemistry

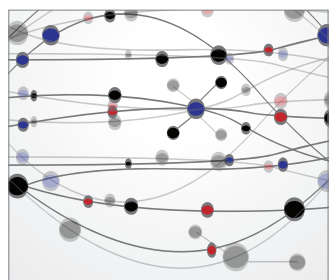

The Scientific World Journal
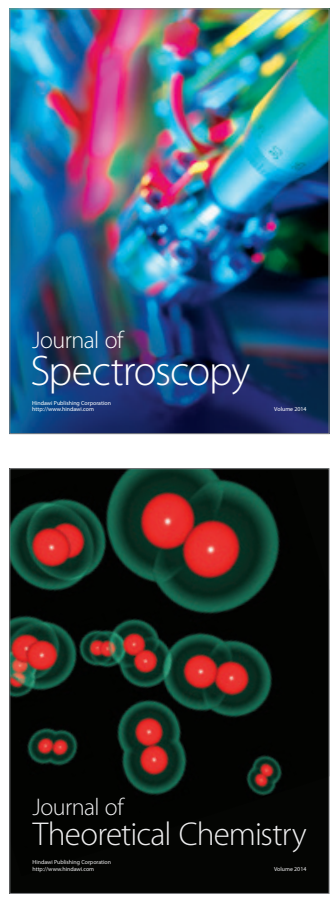
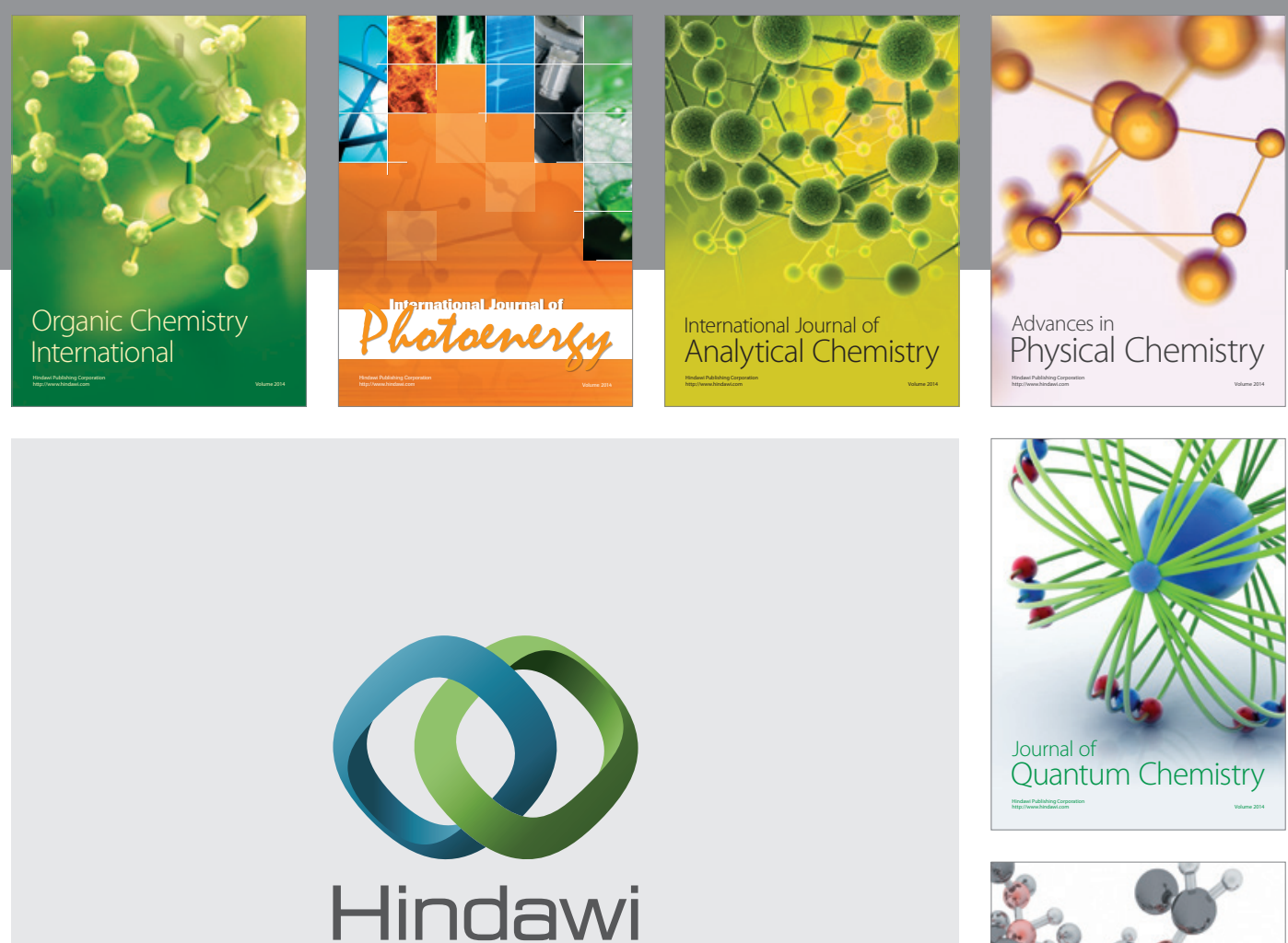

Submit your manuscripts at

http://www.hindawi.com

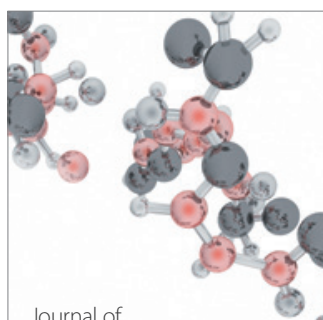

Analytical Methods

in Chemistry

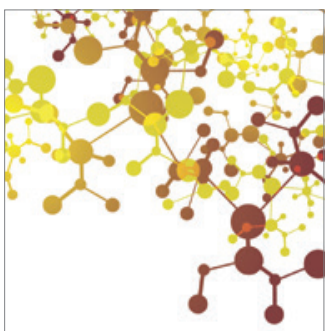

Journal of

Applied Chemistry

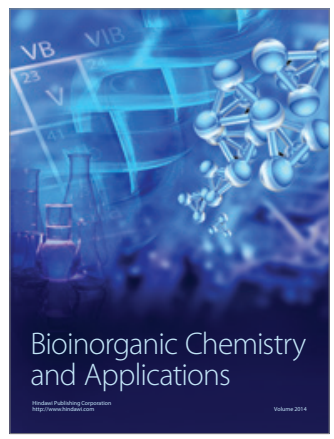

Inorganic Chemistry
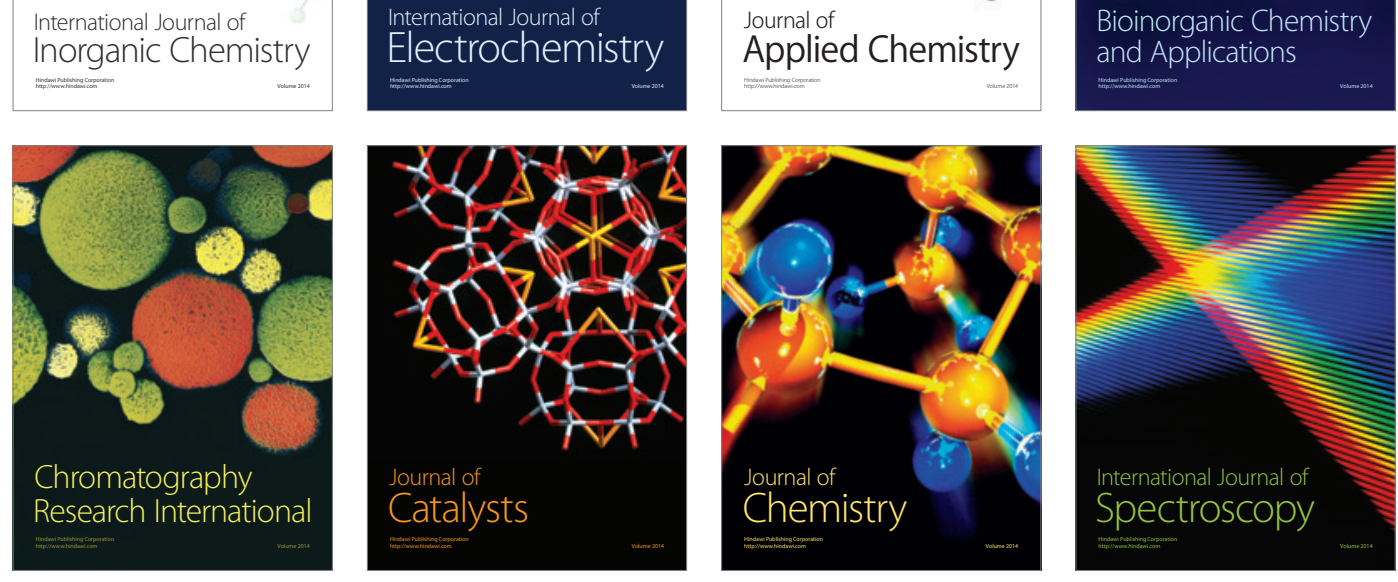